\title{
How to convince your family to let you study
}

\section{Theresia H. Mina}

I come from a family who used to believe that the very purpose of being a woman is simply to get married and raise children. The view was that a young woman needs to attend university so that she is more eligible in the marriage market. I was once taught that women do not need to be too knowledgeable, let alone think of pursuing doctoral study. After all, doctoral study is for men as it requires a lot of brainpower, it is very expensive (and it's not worth investing in sending women for postgraduate study), and most importantly if I were to further my studies I might not find a man who would like to marry me because men are scared of smart women, or so it was said.

At first, I could only see one scenario: get a secretarial job, marry, raise kids. But now I have furthered my studies on my own accord, obtained an MSc and a PhD, and now I work in an ever bigger role in clinical research. I am still doing some secretarial tasks as part of my admin duties, but this is only one out of so many responsibilities.

And yes, I am still going to marry and I plan to raise kids, out of my own freewill.

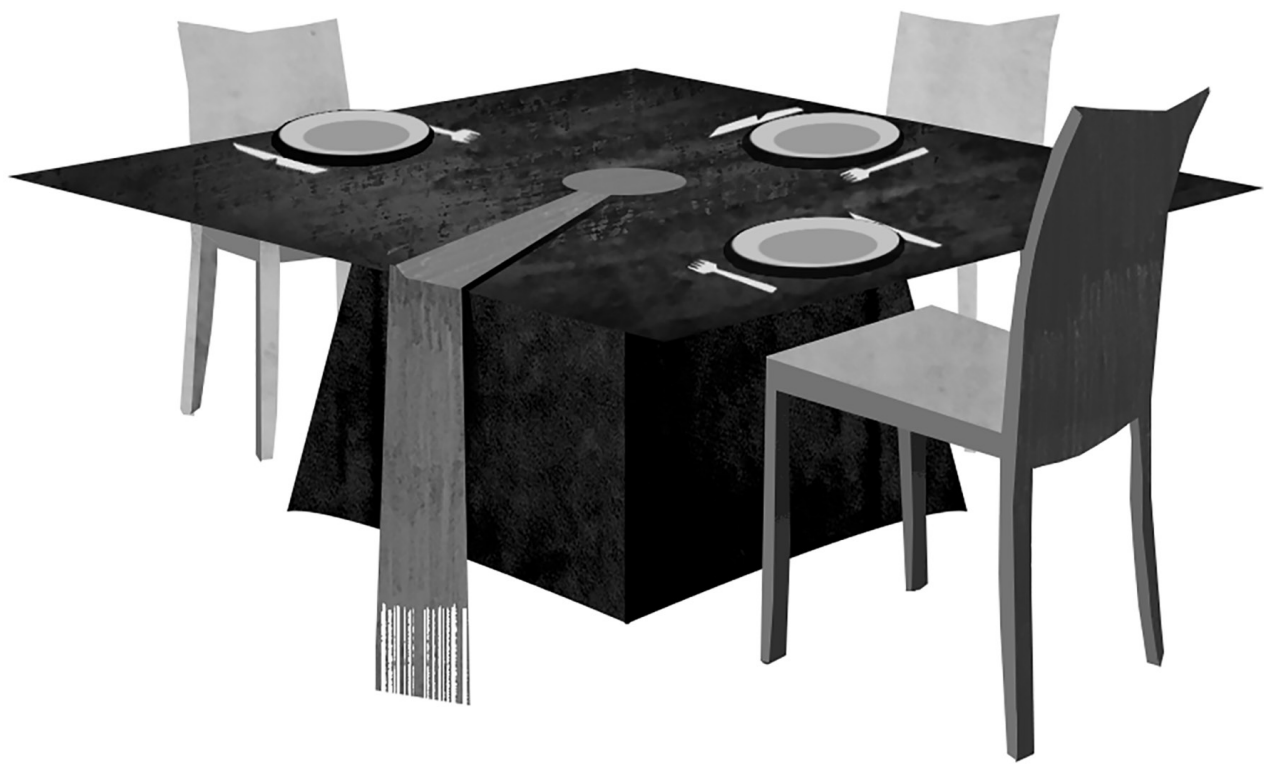




\section{Ingredients}

- Patience.

- Perseverance.

- An excellent track record of what you are passionate about. If you like dancing, you might want to include a dancing competition trophy. If you like basketball, it could be a medal for winning an important match or being the best player. If science is your thing, you might want to gather together your certificates from winning science competitions.

- A bunch of friends sharing similar passions.

- A mentor, teacher, lecturer, professor who believes in your potential and is willing to write you a reference letter.

- A variety of scholarship schemes for which you are eligible to apply.

- A female role model, your favourite dancer, the female basketball player of the year or the top female professor/ minister in your country (or it could simply be your own mentor).

\section{Method}

1. Do your homework: plan in advance to apply for a scholarship, and always have an up-to-date track record.

2. Invite your family elders to a formal dinner or gathering and declare your

EqualBITE How to convince your family to let you study intention to further your studies at least a year in advance of your study plan, the earlier the better. I informed my family regarding my intention to further my studies abroad about three years in advance of my actual plan.

3. Demonstrate your plan. This may include the list of universities you would like to apply to and a list of courses you would like to attend.

4. Showcase your excellent track record.

5. Mention the female role model and how you aspire to be like that. In my case it was helpful to mention that another female student in my class was also thinking of pursuing a similar course so at least my family could see that I was not going to be alone.

6. Show a reference letter from your mentor.

7. Demonstrate how you plan to support yourself financially, such as a list of scholarship applications, and whether you have a plan B if this does not work.

8. Repeat step 1-7 until the concept starts to get ingrained. 


\section{Guidance on}

how to apply for

postgraduate

funding at the

University of

Edinburgh can be

found here: http://

www.ed.ac.uk/

student-funding/

postgraduate/

international.

\section{Cook's tip}

You could also write a diary about how you feel, have tissue boxes to absorb those tears, and read inspirational books to keep your spirits up. You may need to channel your frustration somewhere.

\section{Warnings}

If you receive offensive comments, don't start swearing and being rude to your elders no matter how much you are offended, but do stand your ground firmly.

Be realistic about your family's financial circumstance so that you don't get too disappointed. In the meantime, keep an eye on those competitive scholarships.

There is always a risk that your first plan doesn't work, so have plan $B$ ready. For instance, what type of work would you apply for should your study plan be rejected completely by your parents, family or scholarship bodies? If you receive an offer but not the scholarship, devise plan C on how to fund your study. 